\title{
One DNA Methylation Regulates CHIP Gene Expression of Human Breast Cancer and Predicts Recurrence
}

\author{
TATSUYUKI GOHNO ${ }^{1}$, TORU HANAMURA ${ }^{1}$, MASAFUMI KUROSUMI ${ }^{2}$, \\ HIROYUKI TAKEI ${ }^{3}$, YURI YAMAGUCHI ${ }^{4}$ and SHIN-ICHI HAYASHI ${ }^{1,5}$ \\ ${ }^{1}$ Department of Molecular and Functional Dynamics, \\ Graduate School of Medicine, Tohoku University, Sendai, Japan; \\ ${ }^{2}$ Department of Pathology, Saitama Cancer Center, Saitama, Japan; \\ ${ }^{3}$ Division of Breast Surgery, Saitama Cancer Center, Saitama, Japan; \\ ${ }^{4}$ Research Institute for Clinical Oncology, Saitama Cancer Center, Saitama, Japan; \\ ${ }^{5}$ Center for Regulatory Epigenome and Disease, Graduate School of Medicine, Tohoku University, Sendai, Japan
}

\begin{abstract}
Background/Aim: Carboxyl terminus of Hsc70interacting protein $(C H I P)$ is a ubiquitin ligase that induces ubiquitination and degradation of its target proteins including oncoproteins. We reported that its down-regulation is associated with tumor progression and metastasis of breast cancer. However, the mechanism through which CHIP gene affects cancer cells is unclear. Materials and Methods: We extracted RNA from 45 primary breast cancer samples and compared CHIP mRNA expression profiles, promoter DNA methylation status, and clinicopathological information. Results: CHIP mRNA expression was significantly correlated with the tumor progression status. In several samples, a pinpoint $C p G$ methylation in the CHIP gene promoter region was significantly correlated with CHIP mRNA expression. When this specific $C p G$ was methylated in estrogen receptor (ER)-positive cases, a significant difference in 5-year recurrence was not found compared with ER-negative cases. Conclusion: $C p G$ methylation contributes to the long-term prognosis of ER-positive breast cancer.
\end{abstract}

Recent studies have shown that the ubiquitin-proteasome pathway plays an important role in the regulation of tumor properties (1-3). This pathway controls selective degradation of short-lived proteins including many oncoproteins. Proteins

This article is freely accessible online.

Correspondence to: Tatsuyuki Gohno, Ph.D., Department of Molecular and Functional Dynamics, Graduate School of Medicine, Tohoku University, 2-1 Seiryo-machi, Aoba-ku, Sendai 980-8575, Japan. Tel: +81 227177472, Fax: +81 227177475, e-mail: gohno717@gmail.com

Key Words: Breast cancer recurrence, CHIP, DNA methylation, ER. targeted for proteasomal degradation are sequentially tagged with ubiquitin by ubiquitinating enzymes E1, E2, and E3. In particular, E3 ubiquitin ligases play a pivotal role in ubiquitination. They catalyze the linkage of ubiquitin to the substrate protein, and polyubiquitinated substrates are degraded by the proteasome. E3 ubiquitin ligases have been studied extensively in the field of cancer, and some of them have emerged as therapeutic targets.

Carboxyl terminus of heat shock cognate (Hsc) 70interacting protein (CHIP) is a U-box-type E3 ubiquitin ligase $(4,5)$. CHIP interacts with Hsc70/90 and is involved in ubiquitination and degradation of its target proteins including several oncoproteins (6-8). In breast cancer, CHIP plays a key role in degradation of misfolded estrogen receptor alpha $(E R \alpha)$ and human epidermal growth factor receptor 2 (HER2) (9-11). Recently, we reported that downregulation of CHIP is significantly associated with tumor progression and metastasis of human breast cancer (12). We found that CHIP expression levels are markedly downregulated in advanced tumor samples, such as node metastasis-positive and late-stage cancers, compared with normal samples. Thus, CHIP is closely associated with the malignancy of breast cancer, but the mechanism that regulates its mRNA expression is unclear. To elucidate this mechanism, we focused on a representative gene regulatory mechanism, DNA methylation of the gene promoter region. It is well known that epigenetic regulation such as DNA methylation plays crucial roles in mRNA expression (13-15). Aberrant DNA methylation of $\mathrm{CpG}$ islands in gene promoter regions leads to silencing of several important genes including tumor suppressor genes, and the CHIP gene has a $\mathrm{CpG}$ island in its promoter region. Therefore, in this study, we analyzed the DNA methylation status of the CHIP gene promoter region and compared it with its mRNA expression levels among 45 breast tumor samples. Moreover, to confirm 
Table I. Relationship between CHIP mRNA expression and clinicopathological factors.

\begin{tabular}{|c|c|c|c|c|c|c|c|}
\hline Characteristic & $\mathrm{n}$ & CHIP mRNA & $p$-Value & Characteristic & $\mathrm{n}$ & CHIP mRNA & $p$-Value \\
\hline Age & & & & Stage & & & \\
\hline$<50$ & 12 & $1.77 \pm 1.45$ & 0.2085 & I & 2 & $2.91 \pm 0.76$ & 0.0295 \\
\hline \multirow[t]{2}{*}{$\geq 50$} & 33 & $1.27 \pm 1.44$ & & II & 28 & $1.75 \pm 1.27$ & \\
\hline & & & & III & 9 & $0.69 \pm 1.35$ & \\
\hline ER & & & & IV & 6 & $0.38 \pm 1.72$ & \\
\hline Positive & 25 & $1.57 \pm 1.32$ & 0.5526 & & & & \\
\hline \multirow[t]{2}{*}{ Negative } & 20 & $1.21 \pm 1.60$ & & $\mathrm{~T}$ & & & \\
\hline & & & & 1 & 4 & $2.86 \pm 0.45$ & 0.0614 \\
\hline $\operatorname{PgR}$ & & & & 2 & 29 & $1.46 \pm 1.37$ & \\
\hline Positive & 21 & $1.56 \pm 1.37$ & 0.5851 & 3 & 6 & $0.74 \pm 1.17$ & \\
\hline Negative & 24 & $1.28 \pm 1.52$ & & 4 & 6 & $0.86 \pm 1.95$ & \\
\hline Node Metastasis & & & & $\mathrm{N}$ & & & \\
\hline Positive & 20 & $0.81 \pm 1.54$ & 0.0165 & 0 & 8 & $2.11 \pm 0.95$ & 0.3065 \\
\hline \multirow[t]{2}{*}{ Negative } & 25 & $1.89 \pm 1.19$ & & 1 & 29 & $1.35 \pm 1.55$ & \\
\hline & & & & 2 & 5 & $0.56 \pm 1.30$ & \\
\hline Tumor Size (mm) & & & & 3 & 3 & $1.49 \pm 1.45$ & \\
\hline$<25$ & 17 & $1.69 \pm 1.19$ & 0.468 & & & & \\
\hline \multirow[t]{3}{*}{$\geq 25$} & 28 & $1.23 \pm 1.58$ & & M & & & \\
\hline & & & & 0 & 39 & $1.56 \pm 1.36$ & 0.0950 \\
\hline & & & & 1 & 6 & $0.38 \pm 1.72$ & \\
\hline
\end{tabular}

Significant $p$-Values are shown in bold.

whether the DNA methylation status is associated with clinicopathological characteristics and prognosis, we compared the methylation status with the clinicopathological characteristics and recurrence rate of patients.

\section{Materials and Methods}

Tumor samples. Primary human breast cancer tissues were obtained during surgery from 45 patients after patient consent from 1999 to 2001 at Saitama Cancer Center Hospital (Saitama, Japan), embedded in optimal cutting temperature (OCT), and transferred to Tohoku University. The study was approved by Tohoku University Ethics Committee (Approval No. 2009-81). The estrogen receptor (ER) and progesterone receptor $(\mathrm{PgR})$ protein expression in the samples were determined by enzyme immunoassays. The cut off value for ER and PgR was set at 10 units.

$R N A$ preparation and real-time $R T-P C R$. Several $5 \mu \mathrm{m}$-thick sections were prepared from tumor tissues embedded in OCT and mounted on film-coated glass slides. Then, each section was fixed, dehydrated with methanol, and stained with toluidine blue staining prior to laser capture microdissection (LCM). The sections were also stained with hematoxylin-eosin to determine the outlines of tumor areas. Only outlined tumor areas were microdissected using a Leica LMD7000 (Leica Microsystems GmbH, Wetzlar, Germany). RNA was extracted from the collected tumor cells using an RNeasy Micro Kit (Qiagen, Mississauga, Canada), according to the manufacturer's instructions. Total RNA was converted to first-strand cDNA using a QuantiTect Reverse Transcription Kit (Qiagen). Real-time PCR was performed using a StepOne ${ }^{\mathrm{TM}}$ Real-Time PCR System (Applied Biosystems Inc., Foster City, CA, USA). The oligonucleotides used in real-time
PCR were as follows: forward primer 5'-GGA GAG CTA TGA TGA GGC CAT C-3', reverse primer 5'-AAG TTC AGC CGC TGC TCC T-3', and probe 5'-CTG CAG CGA GCT TAC AGC CTG GC-3' for CHIP; forward primer 5'-GAG TAC TTG CGC TCA GGA GGA-3', reverse primer 5'-ACG TGG ACA TCC GCA AAG A-3', and probe 5'-CAA TGA TCT TGA TCT TCA TTG TGC TGG GTG-3' for $\beta$ actin as the internal control.

DNA preparation and bisulfite sequencing. Several $40 \mu \mathrm{m}$-thick sections containing a large tumor fragment were prepared from tissues embedded in OCT. DNA from these tumor samples was extracted using a QIAamp DNA Mini Kit (Qiagen), according to the manufacturer's instructions. Extracted DNA was treated with bisulfite using an EpiTect Bisulfite Kit (Qiagen), according to the manufacturer's instructions. Then, nested PCR was carried out at $95^{\circ} \mathrm{C}$ for 2 min, followed by 42 cycles ( 40 cycles for $2^{\text {nd }} \mathrm{PCR}$ ) at $95^{\circ} \mathrm{C}$ for $30 \mathrm{~s}, 48^{\circ} \mathrm{C}$ for $30 \mathrm{~s}\left(1 \mathrm{~min}\right.$ for $\left.2^{\text {nd }} \mathrm{PCR}\right), 72^{\circ} \mathrm{C}$ for $1 \mathrm{~min}$, and final extension at $72^{\circ} \mathrm{C}$ for $7 \mathrm{~min}$. The oligonucleotides used in nested PCR were as follows: $1^{\text {st }}$ PCR forward primer 5'-TTG GAT TTA TTA GGG AGG TT-3', $2^{\text {nd }}$ PCR forward primer 5'-TTA AGT TGT TAG GTT AGT AG-3', and common reverse primer 5'-CTA AAC TAC CAT TCT AAA AC-3'. The PCR amplicon was electrophoresed, and DNA from the correctly sized band was extracted using a QIAquick Gel Extraction Kit (Qiagen). The purified DNA was sequenced using an ABI PRISM 3100 Genetic Analyzer (Applied Biosystems Inc.).

Statistical analysis. Statistical analysis was performed with the StatFlex 6.0 software program (Artech Co., Ltd., Osaka, Japan). Comparison of two independent groups was performed with the Mann-Whitney $U$-test. For comparison among three groups or more, the Kruskal-Wallis test was used. $p<0.05$ was considered to be statistically significant. 


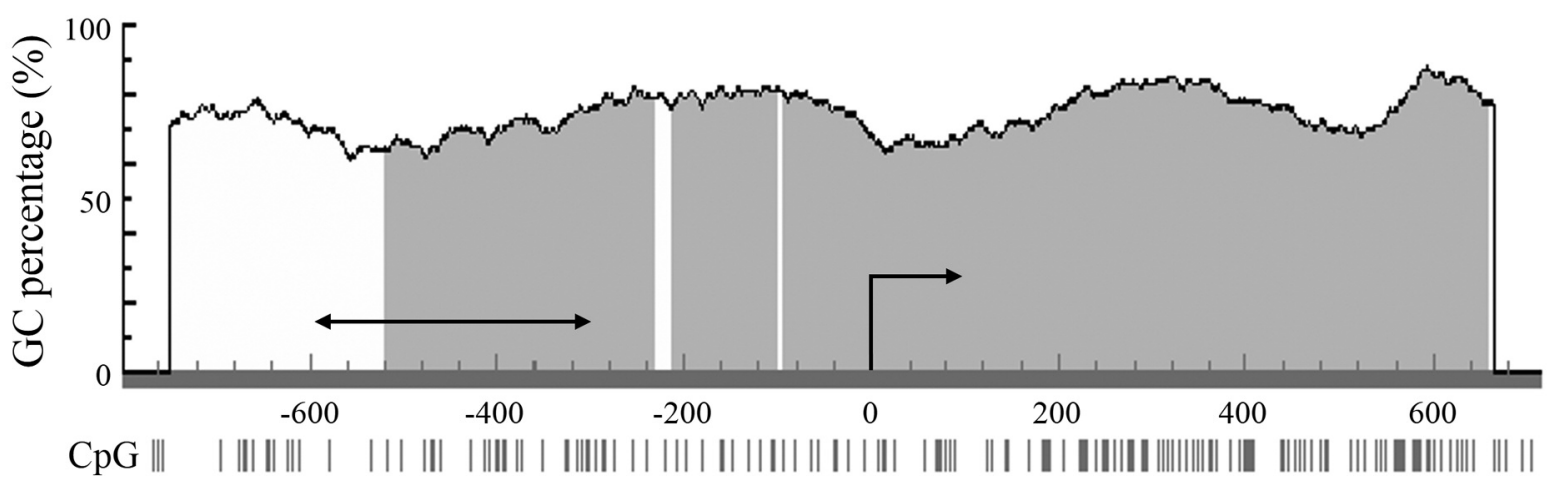

Figure 1. Analyzed region in the CHIP gene promoter. The region analyzed by bisulfite DNA sequencing was $249 \mathrm{bp}$ from -600 bp to -352 bp of the transcription initiation site in the CHIP gene. The horizontal arrow indicates the sequence of the analyzed region, and the curved arrow indicates the transcription initiation site. The gray area indicates a $C p G$ island.

\section{Results}

CHIP mRNA expression significantly correlates with tumor progression of breast cancer tissue. To examine the role of CHIP gene in breast cancer, we assessed the relationship between the CHIP mRNA expression and clinicopathological characteristics of the cases (Table I). CHIP mRNA was significantly decreased with lymph node metastasis and stage progression. Other factors related with tumor progression such as the tumor size and TNM status tended to be associated with lower CHIP mRNA expression although without statistical significance. The CHIP gene is an ER target with an ERE half site in its promoter region, but CHIP mRNA expression was not significantly correlated with expression of ER protein or its target gene PgR. These results suggest that another transcription activation mechanism regulates the expression of CHIP gene in addition to ER-dependent transcription.

Promoter methylation of the CHIP gene regulates its expression. We hypothesized that down-regulation of CHIP expression in breast cancer occurred through promoter methylation as a representative epigenetic regulation system. Therefore, bisulfite-specific PCR was performed using DNA extracted from the samples, and the DNA methylation status was determined by analysis of the sequence of the PCR product. The analyzed region was $249 \mathrm{bp}$ from $-600 \mathrm{bp}$ to $352 \mathrm{bp}$ of the transcription initiation site in the CHIP gene (Figure 1). This region was identified as a domain containing the region closely related to transcriptional activation using a luciferase reporter assay in preliminary experiments (data not shown). Results from the methylation analysis of the 38 breast cancer tissues indicated that methylation occurred in the $4^{\text {th }}$ to $9^{\text {th }} \mathrm{CpG}$ sites of the region in $50 \%(19 / 38)$ of the samples (Figure 2). Samples with no less than 50\% (three point) methylation of these six $\mathrm{CpG}$ sites were designated as positive for methylation. Using this threshold, samples were divided into methylation (M) and unmethylation (U) groups. We then compared the methylation status of $\mathrm{M}$ and $\mathrm{U}$ groups with the CHIP mRNA expression status (Figure 3A). Although there was no statistical significance, the methylation status seemed to correlate with CHIP mRNA expression. Interestingly, there were six samples with only the $9^{\text {th }} \mathrm{CpG}$ (CpG9) unmethylated in the $\mathrm{M}$ group, whereas one sample only had $\mathrm{CpG} 9$ methylated in the $\mathrm{U}$ group (Figure 2). Therefore, we divided the samples into CpG9 M and $\mathrm{CpG} 9 \mathrm{U}$ groups and compared the $\mathrm{CpG} 9$ methylation status with the CHIP mRNA expression status (Figure 3B). Statistical analysis revealed significant intergroup differences, namely CHIP mRNA expression was significantly decreased in the CpG9 $\mathrm{M}$ group compared with the CpG9 U group. However, no significant difference in CHIP mRNA expression was observed between groups with other $\mathrm{CpG}$ pinpoint methylations (data not shown).

DNA methylation coordinately regulates CHIP mRNA expression with ER. As shown in Table I, the ER status was not correlated with CHIP mRNA expression, even though CHIP is an ER target gene. It was assumed that this pinpoint CpG9 methylation interfered with the mechanism through which ER regulates CHIP mRNA expression. Therefore, ERpositive and -negative groups were classified into $\mathrm{M}$ and $\mathrm{U}$ groups, and CHIP mRNA expression of the four groups was compared (Figure 4). Interestingly, remarkable down-regulation of CHIP mRNA expression was observed only in the ERnegative $M$ group. In contrast, the other three groups maintained high mRNA expression, especially the ER-negative $\mathrm{U}$ group $(p<0.05)$. These results suggest that CHIP gene is 


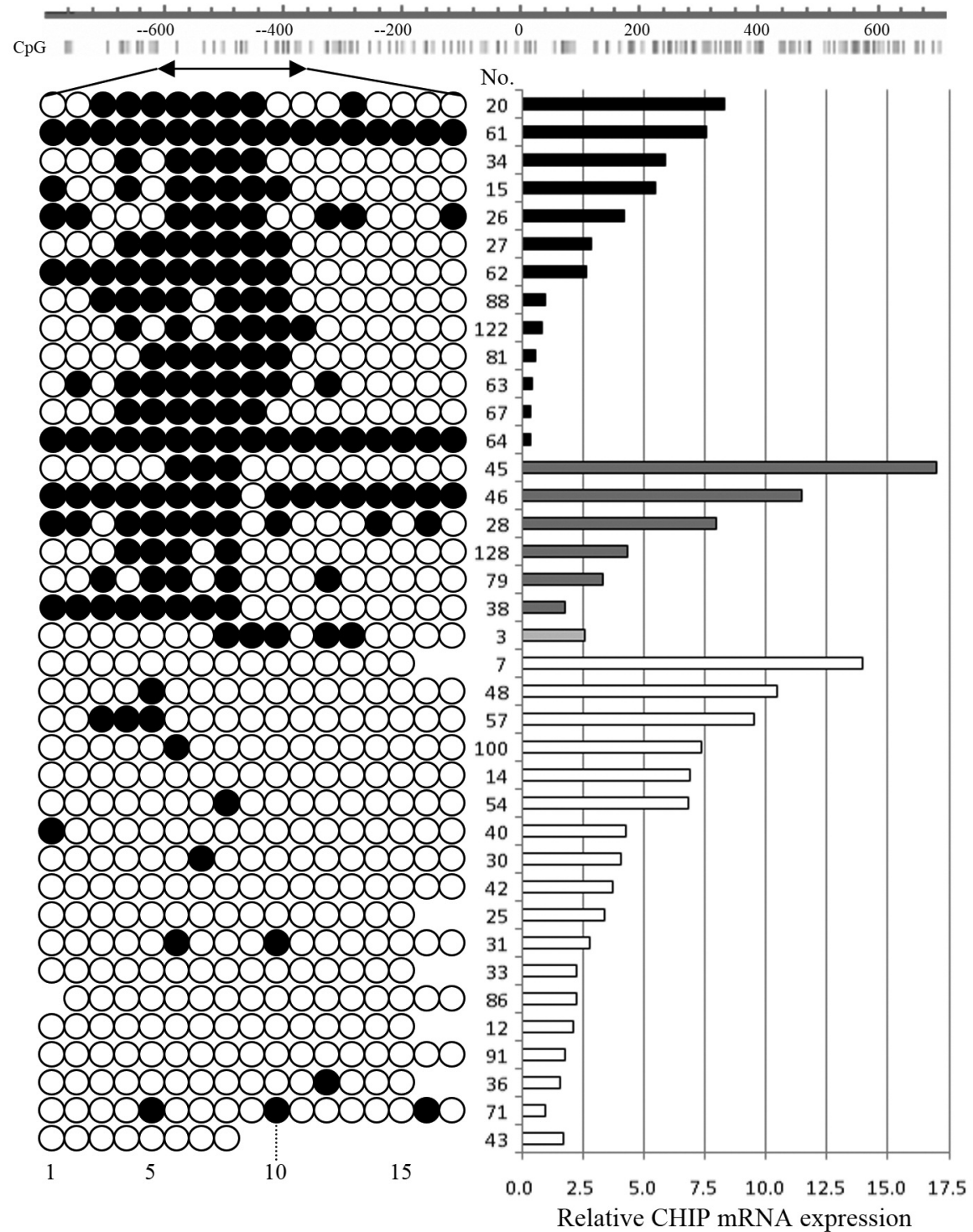

Figure 2. DNA methylation status of the CHIP gene in breast tumor tissues. (Left) The region analyzed by bisulfite DNA sequencing included 17 $C p G$ sites. White circles indicate unmethylated CpG sites, and black circles indicate methylated CpG sites. Samples with no less than $50 \%$ (three point) methylation in the $4^{\text {th }}$ to $9^{\text {th }} C p G$ sites were designated as the region-methylated group. (Right) CHIP mRNA expression levels of four groups divided by region methylation and the CpG9 methylation status. Black bars are the region-methylated/CpG9-methylated group. Gray bars are the region-methylated/CpG9-unmethylated group. Light gray bars are the region-unmethylated/CpG9-methylated group. White bars are the regionunmethylated/CpG9-unmethylated group.

complimentarily regulated by ER and DNA methylation. Specifically, the reason that there was no difference in ERpositive and -negative groups was $\mathrm{CpG}$ methylation.

CpG9 methylation of the CHIP gene predicts long term recurrence. CHIP expression suppresses distal metastasis (12). Therefore, we investigated whether CpG9 methylationregulated expression was associated with tumor recurrence after 5 years. Although the number of patients with recurrence in the ER-positive group was significantly lower than that in the ER-negative group, some metastatic recurrence was observed in patients despite ER positivity (Figure 5A). In the analysis of the four groups divided by ER positivity and CpG9 methylation (Figure 5B), the recurrence rate in the ER-positive/GpG9 $\mathrm{U}$ group was significantly lower than that in the two ER-negative groups. 

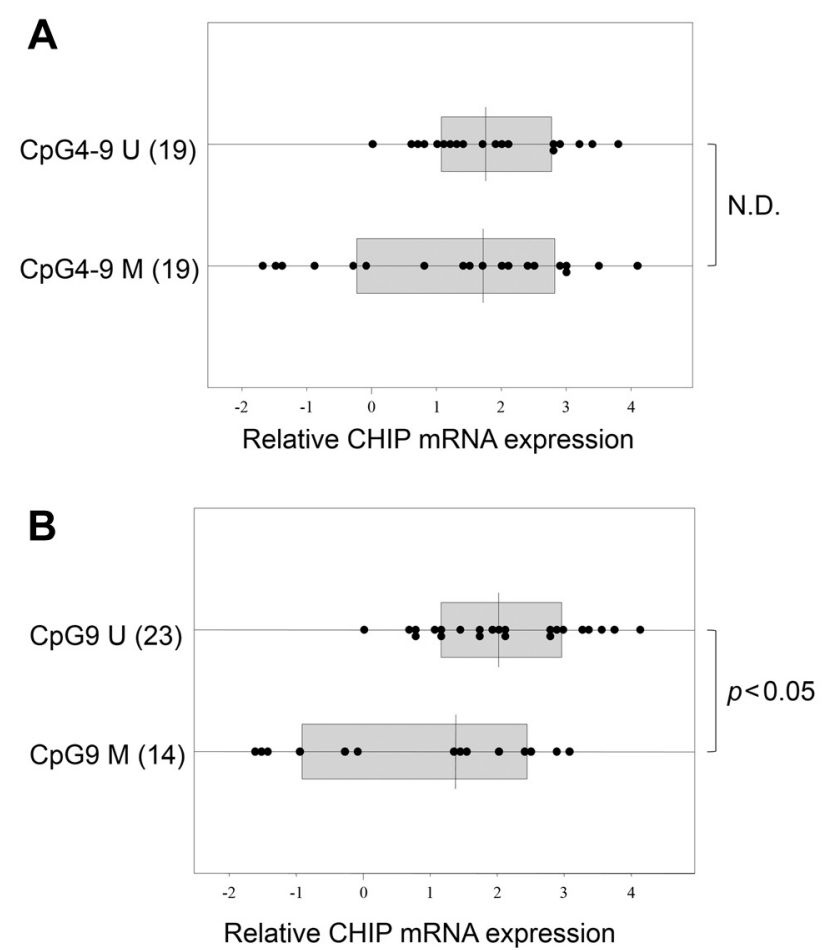

Figure 3. CHIP mRNA expression level classified by the methylation status in patients. The intergroup difference of CHIP mRNA expression in patients divided into methylated or unmethylated groups is shown. Box plots show the intergroup difference of the (A) CpG4-9 and (B) $C p G 9$ methylation status in each group.

However, in the ER-positive/CpG9 M group, there was no significant difference in the recurrence rate compared with the two ER-negative groups. These results suggest that ERpositive breast cancer can be divided in two prognostic groups by the CpG9 methylation status. Thus, ER and methylation status may be valuable for prognosis prediction.

\section{Discussion}

When determining a therapeutic strategy for breast cancer, the resistance mechanism is one of the most important considerations. ER is the factor that relates most strongly to breast cancer proliferation and progression, and is used to predict the efficacy of hormonal therapy (16-20). Generally, although ER-positive breast cancer is considered to have a good prognosis compared with ER-negative breast cancer, it is not necessarily an indicator of long-term recurrence. According to the U.S. patient registration database in 19922007 (21), ER-negative cases have a peak recurrence rate at an early stage compared to 1-3 years postoperatively, and the rate decreases over time. However, ER-positive cases maintain a constant rate of recurrence in the long term,

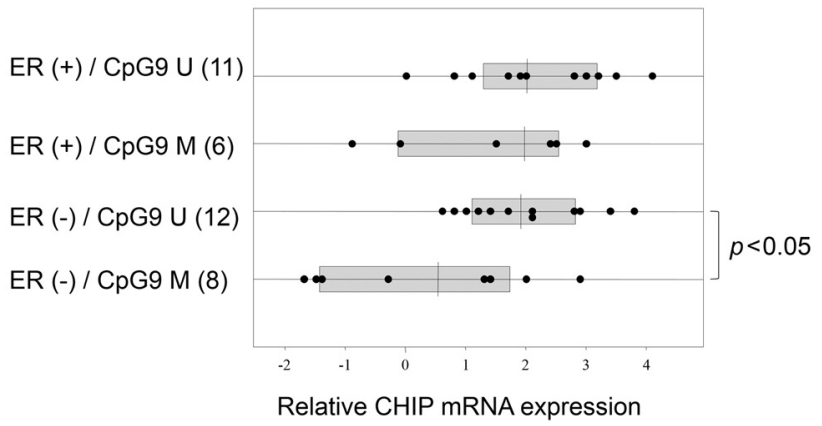

Figure 4. CHIP mRNA expression level classified by the methylation status and ER in patients. The intergroup difference of CHIP $m R N A$ expression in patients divided into methylated or unmethylated and ERpositive or -negative groups is shown. Box plots show the intergroup difference of the CpG9 methylation status in each group.

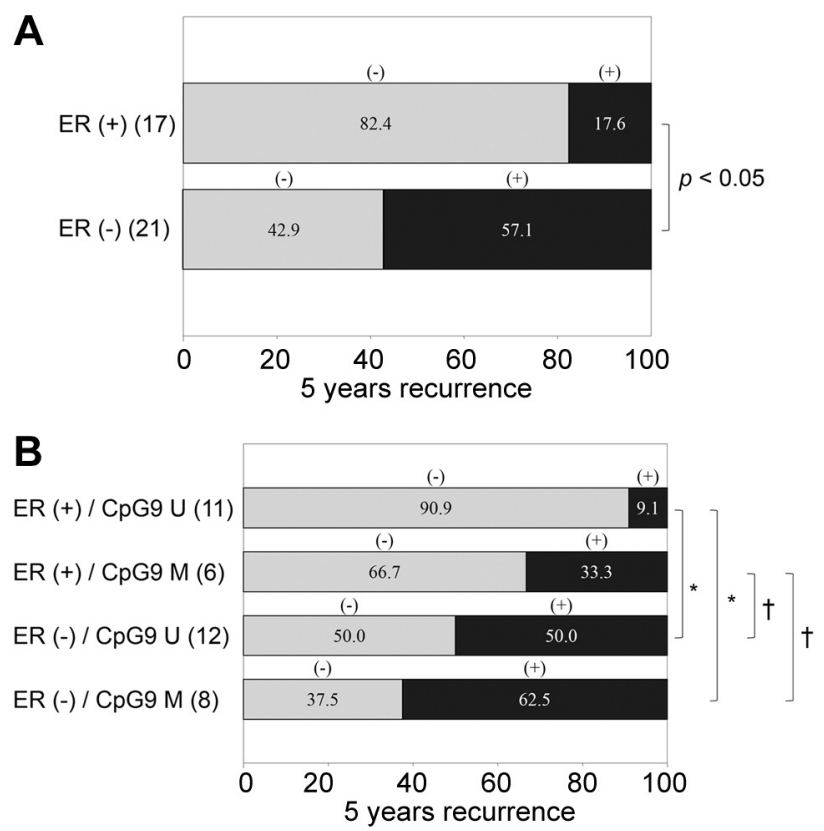

Figure 5. Recurrence rate after 5 years in patients divided by ER $\alpha$ expression and CpG9 methylation. The intergroup difference of the recurrence rate after 5 years in patients divided into ER positive/negative and CPG9-methylated/unmethylated groups is shown.

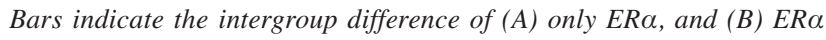
and $C p G 9$ methylation in each group. Gray bars indicate the nonrecurrence group, and black bars indicate the recurrence group. $* p<0.05,+N . D$.

which is higher than the rate of ER-negative cases at 5 years postoperatively. According to reports of the recurrence risk in many countries, the recurrence risk of ER-positive breast cancer exceeds that of ER-negative breast cancer at 3-4 years postoperatively (21). It is necessary to follow-up patients 
ER-positive breast cancer for several years postoperatively for recurrence. Therefore, new additional indices are required for ER-positive breast cancer.

CHIP is an ER target gene with an important role in breast cancer (4-12). CHIP mRNA expression in clinical samples was negatively correlated with tumor progression, especially lymph node metastasis and advanced stage. We have reported that CHIP promotes degradation of SRC-3 (12), an important coactivator of ER (22-25), as a target of ubiquitination in breast cancer. SRC-3 elevates the transcriptional activity of Smad2 and expression of Twist1, and causes tumor metastasis $(12,26)$. Additionally, SRC-3 causes resistance to endocrine therapy in primary breast cancer by targeting phosphorylation pathways such as HER2 $(27,28)$. Similar to previous reports, in our samples, SRC-3 degradation may have been associated with repression of tumor progression and metastasis. It has been reported that CHIP expression leads to regression of cancer. Although CHIP is a target gene of ER, its expression was not correlated with ER expression in previous reports or this study. Thus, there may be mechanisms regulating its expression other than those mediated by ER.

To delineate the expression mechanism, we focused on the epigenetic regulation of the $C H I P$ gene and analyzed the DNA methylation status of its promoter region in clinical samples. Methylation was identified in the $4^{\text {th }}$ to $9^{\text {th }} \mathrm{CpG}$ sites in $50 \%$ of the samples. Furthermore, methylation of the $9^{\text {th }} \mathrm{CpG}$ in this region was significantly correlated with down-regulation of CHIP mRNA expression. Analysis of transcription factor binding sites in this domain revealed binding of c-Ets, c-Myb, and c-Rel, which are methylation-sensitive transcription factors. If $\mathrm{CpG}$ islands are methylated, binding of these transcriptional factors is inhibited by the methyl group itself or a methyl CpG-binding protein, and transcriptional activity is down-regulated $(29,30)$. Therefore, methylation transcription factor recognition sequence in this region may be a mechanism through which CHIP expression is regulated.

CHIP mRNA expression did not correlate with expression of ER protein, a known CHIP genetic control factor (12). To investigate the mechanism that regulates transcription of the CHIP gene independently of ER, the samples were divided into four groups by positivity for the ER and CpG9 methylation. High expression of CHIP mRNA was observed in the CpG9 $\mathrm{U}$ group regardless of ER expression. Moreover, in the CpG9 M group, down-regulation of CHIP mRNA was observed only in the ER-negative group. Because CHIP mRNA was highly expressed except in the ERnegative/CpG9 $\mathrm{M}$ group, CHIP gene expression may be regulated by two mechanisms employing ER and/or CpG9 methylation. Furthermore, methylation of $\mathrm{CpG} 9$ and its nearby region was significantly enhanced in a sample from a $<50$ years old (data not shown). This result suggests that the down-regulation by DNA methylation occurs in a young population, and that the regulation mechanism involves malignancies such as juvenile breast cancer.

We also analyzed the tumor recurrence rate. ER is the one of the most valuable prognostic factors of breast cancer (1620). Our analysis also reflected this tendency. The ERpositive group showed a significantly lower recurrence rate than the ER-negative group. However, in the ER-positive group, there were some patients with cancer recurrence. Even in ER-positive cases, the CpG9-methylated group showed no significant difference in recurrence rate compared to each of the ER-negative methylation groups. Previously, we reported the relationship between ER and CHIP protein expression (31), and recurrence-free survival was significantly better in the ER-positive cases with high CHIP expression than in ER-negative cases. However, although positive for ER, such cases with low CHIP expression tended to have worse recurrence-free survival than those with high CHIP expression. Additionally, there are several reports of expression regulated by pinpoint $\mathrm{CpG}$ methylation in breast cancer $(32,33)$. Our results and these reports suggest that this methylation of $\mathrm{CpG} 9$ can also predict the long-term prognosis of ER-positive breast cancer.

It is difficult to specify the prognosis of many patients by only one or a few factors such as protein expression. Additional factors that increase the accuracy of prognosis prediction in combination with existing factors should be identified. Epigenetic modifications such as DNA methylation or histone modification are powerful predictive factors and should be further investigated.

\section{Conflicts of Interest}

The Authors have no conflicts of interest to declare in relation to this study.

\section{Authors' Contributions}

Tatsuyuki Gohno: Conceptualization, Methodology, Formal analysis, Investigation, Writing - original draft; Toru Hanamura: Methodology, Investigation, Writing - review and editing; Masafumi Kurosumi: Methodology, Investigation, Writing - review and editing; Hiroyuki Takei: Methodology, Investigation, Writing review and editing; Yuri Yamaguchi: Methodology, Investigation, Writing - review and editing; Shin-Ichi Hayashi: Conceptualization, Methodology, Investigation, Writing - review and editing, Supervision, project administration, funding acquisition.

\section{Acknowledgements}

The Authors thank Toshifumi Niwa, Yuko Seino and Chika Tazawa for valuable assistance and comments on this study. The Authors also thank M. Arico from Edanz Group (www.edanzediting.com/ac) for editing a draft of this manuscript. This study was supported in part by a Grant-in-Aid for Scientific Research from the Ministry of Education, Science, Sports and Culture of Japan, a Grant-in-Aid for 
Cancer Research from the Ministry of Health, Labor, and Welfare, Japan, the Program for Promotion of Fundamental Studies in Health Sciences of the National Institute of Biomedical Innovation (NIBIO), and a Grant from the Smoking Research Foundation.

\section{References}

1 Hochstrasser M: Ubiquitin-dependent protein degradation. Annu Rev Genet 30: 405-439, 1996. PMID: 8982460. DOI: 10.1146/ annurev.genet.30.1.405

2 Hershko A and Ciechanover A: The ubiquitin system. Annu Rev Biochem 67: 425-479, 1998. PMID: 9759494. DOI: 10.1146/annurev.biochem.67.1.425

3 Konstantinova IM, Tsimokha AS and Mittenberg AG: Role of proteasomes in cellular regulation. Int Rev Cell Mol Biol 267: 59124, 2008. PMID: 18544497. DOI: 10.1016/S1937-6448(08) 00602-3

4 Ballinger CA, Connell P, Wu Y, Hu Z, Thompson LJ, Yin LY and Patterson C: Identification of CHIP, a novel tetratricopeptide repeatcontaining protein that interacts with heat shock proteins and negatively regulates chaperone functions. Mol Cell Biol 19(6): 4535-4545, 1999. PMID: 10330192. DOI: 10.1128/MCB.19.6.4535

5 Connell P, Ballinger CA, Jiang J, Wu Y, Thompson LJ, Höhfeld $\mathrm{J}$ and Patterson C: The co-chaperone CHIP regulates protein triage decisions mediated by heat-shock proteins. Nat Cell Biol 3(1): 93-96, 2001. PMID: 11146632. DOI: 10.1038/35050618

6 Meacham GC, Patterson C, Zhang W, Younger JM and Cyr DM: The Hsc70 co-chaperone CHIP targets immature CFTR for proteasomal degradation. Nat Cell Biol 3(1): 100-105, 2001. PMID: 11146634. DOI: 10.1038/35050509

7 Esser C, Scheffner M and Höhfeld J: The chaperone-associated ubiquitin ligase CHIP is able to target p53 for proteasomal degradation. J Biol Chem 280(29): 27443-27448, 2005. PMID: 15911628. DOI: $10.1074 /$ jbc.M501574200

8 Li D, Marchenko ND, Schulz R, Fischer V, Velasco-Hernandez T, Talos $\mathrm{F}$ and Moll UM: Functional inactivation of endogenous MDM2 and CHIP by HSP90 causes aberrant stabilization of mutant p53 in human cancer cells. Mol Cancer Res 9(5): 577-588, 2011. PMID: 21478269. DOI: 10.1158/1541-7786.MCR-10-0534

9 Tateishi Y, Kawabe Y, Chiba T, Murata S, Ichikawa K, Murayama A, Tanaka K, Baba T, Kato S and Yanagisawa J: Ligand-dependent switching of ubiquitin-proteasome pathways for estrogen receptor. EMBO J 23(24): 4813-4823, 2004. PMID: 15538384. DOI: $10.1038 /$ sj.emboj.7600472

10 Fan M, Park A and Nephew KP: CHIP (carboxyl terminus of Hsc70-interacting protein) promotes basal and geldanamycininduced degradation of estrogen receptor-alpha. Mol Endocrinol 19(12): 2901-2914, 2005. PMID: 16037132. DOI: 10.1210/ me.2005-0111

$11 \mathrm{Xu} \mathrm{W}$, Marcu M, Yuan X, Mimnaugh E, Patterson C and Neckers L: Chaperone-dependent E3 ubiquitin ligase CHIP mediates a degradative pathway for c-ErbB2/Neu. Proc Natl Acad Sci USA 99(20): 12847-12852, 2002. PMID: 12239347. DOI: $10.1073 /$ pnas.202365899

12 Kajiro M, Hirota R, Nakajima Y, Kawanowa K, So-ma K, Ito I, Yamaguchi Y, Ohie SH, Kobayashi Y, Seino Y, Kawano M, Kawabe Y, Takei H, Hayashi S, Kurosumi M, Murayama A, Kimura $\mathrm{K}$ and Yanagisawa J: The ubiquitin ligase CHIP acts as an upstream regulator of oncogenic pathways. Nat Cell Biol 11(3): 312-319, 2009. PMID: 19198599. DOI: 10.1038/ncb1839
13 Bird A: DNA methylation patterns and epigenetic memory. Genes Dev 16(1): 6-21, 2002. PMID: 11782440. DOI: $10.1101 / \mathrm{gad} .947102$

14 Reik W: Stability and flexibility of epigenetic gene regulation in mammalian development. Nature 447(7143): 425-432, 2007. PMID: 17522676. DOI: 10.1038/nature05918

15 Esteller M: Epigenetics in cancer. N Engl J Med 358(11): 11481159, 2008. PMID: 18337604. DOI: 10.1056/NEJMra072067

16 Hammond ME, Hayes DF, Dowsett M, Allred DC, Hagerty KL, Badve S, Fitzgibbons PL, Francis G, Goldstein NS, Hayes M, Hicks DG, Lester S, Love R, Mangu PB, McShane L, Miller K, Osborne CK, Paik S, Perlmutter J, Rhodes A, Sasano H, Schwartz JN, Sweep FC, Taube S, Torlakovic EE, Valenstein P, Viale G, Visscher D, Wheeler T, Williams RB, Wittliff JL and Wolff AC: American Society of Clinical Oncology/College Of American Pathologists guideline recommendations for immunohistochemical testing of estrogen and progesterone receptors in breast cancer. $\mathrm{J}$ Clin Oncol 28(16): 2784-2795, 2010. PMID: 20404251. DOI: 10.1200/JCO.2009.25.6529

17 Burstein HJ, Prestrud AA, Seidenfeld J, Anderson H, Buchholz TA, Davidson NE, Gelmon KE, Giordano SH, Hudis CA, Malin J, Mamounas EP, Rowden D, Solky AJ, Sowers MR, Stearns V, Winer EP, Somerfield MR, Griggs JJ and American Society of Clinical Oncology: American Society of Clinical Oncology clinical practice guideline: update on adjuvant endocrine therapy for women with hormone receptor-positive breast cancer. J Clin Oncol 28(23): 3784-3796, 2010. PMID: 20625130. DOI: 10.1200/JCO.2009.26.3756

18 Pujol P, Daures JP, Thezenas S, Guilleux F, Rouanet P and Grenier J: Changing estrogen and progesterone receptor patterns in breast carcinoma during the menstrual cycle and menopause. Cancer 83(4): 698-705, 1998. PMID: 9708933.

19 Hayashi SI, Eguchi H, Tanimoto K, Yoshida T, Omoto Y, Inoue A, Yoshida N and Yamaguchi Y: The expression and function of estrogen receptor alpha and beta in human breast cancer and its clinical application. Endocr Relat Cancer 10(2): 193-202, 2003. PMID: 12790782. DOI: 10.1677/erc.0.0100193

20 Hayashi S, Niwa $\mathrm{T}$ and Yamaguchi Y: Estrogen signaling pathway and its imaging in human breast cancer. Cancer Sci 100(10): 1773-1778, 2009. PMID: 19575750. DOI: 10.1111/ j.1349-7006.2009.01243.x

21 Lin NU and Winer EP: Advances in adjuvant endocrine therapy for postmenopausal women. J Clin Oncol 26(5): 798-805, 2008. PMID: 18258989. DOI: 10.1200/JCO.2007.15.0946

22 Anzick SL, Kononen J, Walker RL, Azorsa DO, Tanner MM, Guan XY, Sauter G, Kallioniemi OP, Trent JM and Meltzer PS: AIB1, a steroid receptor coactivator amplified in breast and ovarian cancer. Science 277(5328): 965-968, 1997. PMID: 9252329. DOI: $10.1126 /$ science. 277.5328 .965

23 Chen H, Lin RJ, Schiltz RL, Chakravarti D, Nash A, Nagy L, Privalsky ML, Nakatani Y and Evans RM: Nuclear receptor coactivator ACTR is a novel histone acetyltransferase and forms a multimeric activation complex with $\mathrm{P} / \mathrm{CAF}$ and $\mathrm{CBP} / \mathrm{p} 300$. Cell 90(3): 569-580, 1997. PMID: 9267036. DOI: 10.1016/ s0092-8674(00)80516-4

24 Takeshita A, Cardona GR, Koibuchi N, Suen CS and Chin WW: TRAM-1, A novel 160-kDa thyroid hormone receptor activator molecule, exhibits distinct properties from steroid receptor coactivator-1. J Biol Chem 272(44): 27629-27634, 1997. PMID: 9346901. DOI: $10.1074 /$ jbc.272.44.27629 
25 Torchia J, Rose DW, Inostroza J, Kamei Y, Westin S, Glass CK and Rosenfeld MG: The transcriptional co-activator $\mathrm{p} / \mathrm{CIP}$ binds CBP and mediates nuclear-receptor function. Nature 387(6634): 677-684, 1997. PMID: 9192892. DOI: $10.1038 / 42652$

26 Thuault S, Valcourt U, Petersen M, Manfioletti G, Heldin CH and Moustakas A: Transforming growth factor-beta employs HMGA2 to elicit epithelial-mesenchymal transition. J Cell Biol 174(2): 175-183, 2006. PMID: 16831886. DOI: 10.1083/ jcb.200512110

27 Bouras T, Southey MC and Venter DJ: Overexpression of the steroid receptor coactivator AIB1 in breast cancer correlates with the absence of estrogen and progesterone receptors and positivity for p53 and HER2/neu. Cancer Res 61(3): 903-907, 2001. PMID: 11221879.

28 Shou J, Massarweh S, Osborne CK, Wakeling AE, Ali S, Weiss $\mathrm{H}$ and Schiff R: Mechanisms of tamoxifen resistance: increased estrogen receptor-HER2/neu cross-talk in ER/HER2-positive breast cancer. J Natl Cancer Inst 96(12): 926-935, 2004. PMID: 15199112. DOI: $10.1093 /$ jnci/djh166

29 Clouaire T and Stancheva I: Methyl-CpG binding proteins: specialized transcriptional repressors or structural components of chromatin? Cell Mol Life Sci 65(10): 1509-1522, 2008. PMID: 18322651. DOI: 10.1007/s00018-008-7324-y

30 Ooi SK and Bestor TH: The colorful history of active DNA demethylation. Cell 133(7): 1145-1148, 2008. PMID: 18585349. DOI: 10.1016/j.cell.2008.06.009
31 Kurozumi S, Yamaguchi Y, Hayashi S, Hiyoshi H, Suda T, Gohno T, Matsumoto H, Takei H, Horiguchi J, Takeyoshi I, Oyama T and Kurosumi M: Prognostic value of the ubiquitin ligase carboxyl terminus of the Hsc70-interacting protein in postmenopausal breast cancer. Cancer Med 5(8): 1873-1882, 2016. PMID: 27334118. DOI: $10.1002 / \mathrm{cam} 4.780$

32 Tsuboi K, Nagatomo T, Gohno T, Higuchi T, Sasaki S, Fujiki N, Kurosumi M, Takei H, Yamaguchi Y, Niwa T and Hayashi SI: Single CpG site methylation controls estrogen receptor gene transcription and correlates with hormone therapy resistance. J Steroid Biochem Mol Biol 171: 209-217, 2017. PMID: 28412323. DOI: 10.1016/j.jsbmb.2017.04.001

33 Fürst RW, Kliem H, Meyer HH and Ulbrich SE: A differentially methylated single $\mathrm{CpG}$-site is correlated with estrogen receptor alpha transcription. J Steroid Biochem Mol Biol 130(1-2): 96104, 2012. PMID: 22342840. DOI: 10.1016/j.jsbmb.2012.01.009

Received November 25, 2021

Revised December 13, 2021

Accepted December 14, 2021 